\title{
Magnetic Solid-Phase Extraction and in Situ Derivatization for Determining Phytohormones and in Oilseeds by Ultra-Performance Liquid Chromatography-tandem Mass Spectrometry
}

\author{
Zhoufei Luo \\ Hunan Agricultural University \\ Mengwei Xu \\ Hunan Agricultural University \\ Ruozhong Wang \\ Hunan Agricultural University \\ Xiubing Liu \\ Hunan Agricultural University \\ Langtao Xiao ( $\nabla$ ltxiao@hunau.edu.cn) \\ Hunan Agricultural University https://orcid.org/0000-0003-4283-9077
}

\section{Research}

Keywords: magnetic solid phase extraction, in situ derivatization, oilseeds, phytohormones, ultra-high performance liquid chromatography-tandem mass spectrometry

Posted Date: June 24th, 2020

DOI: https://doi.org/10.21203/rs.3.rs-37416/v1

License: (c) (i) This work is licensed under a Creative Commons Attribution 4.0 International License. Read Full License 


\section{Abstract}

Background: Phytohormones are a group of naturally occurring signaling molecules which influence physiological processes of oil crops. Simultaneous determination of multiple phytohormones in oilseeds is still a challenge due to their trace concentrations, species diversity, and lipid interference. Therefore, a simple and selective method for the simultaneous determination of multiple phytohormones in oilseeds is urgently needed.

Results: In this study, the $\mathrm{Fe}_{3} \mathrm{O}_{4} @ \mathrm{Ti}_{3} \mathrm{C}_{2} @ \beta$-CD nanoparticles were successfully synthesized and used for the first time as an adsorbent for the magnetic dispersive solid-phase extraction of phytohormones from oilseeds. The magnetic dispersive solid-phase extraction and in situ derivation by the addition of $\mathrm{N}$-(3-dimethylaminopropyl)-N'-ethylcarbodiimide (EDC) were ingeniously combined. This efficient pre-treatment method integrated the extraction, purification, and derivatization processes into one single step. Several parameters affecting the efficiency of extraction and derivatization were evaluated.

Under the optimized analysis conditions, satisfactory methodological performance was achieved. High linearities $\left(R^{2}>0.9928\right)$ at three spiked levels, as well as the low matrix effect (ranged from $16.63 \%$ to $17.06 \%$ ) and limits of detection $(0.89-13.62 \mathrm{pg} / \mathrm{mL})$ were also obtained. The intra and inter-day relative standard deviations (RSDs) were less than $13.7 \%$ and $11.6 \%$, respectively. The recoveries were ranged from $80.4 \%$ to $115.1 \%$. This method was successfully employed for analyzing 12 phytohormones in different oilseeds samples.

Conclusion: A simple and sensitive method based on the magnetic solid phase extraction integrated with in situ derivations for the profiling of 12 phytohormones, including 9 gibberellins (GAs), indole-3-acetic acid (IAA), abscisic acid (ABA), and jasmonic acid (JA) in a single rapeseed seed was developed by using ultra-performance liquid chromatography-tandem mass spectrometry (UPLC-MS/MS).

\section{Background}

Phytohormones are naturally occurring signaling molecules attributing to the regulation of plant growth and development [1]. These molecules are present at trace amounts in plant tissues, and their regulatory mechanisms frequently rely on the complex crosstalk networks among different classes of phytohormones [2, 3]. The study of multiple phytohormones such as Gibberellins (GAs), indole-3-acetic acid (IAA), abscisic acid (ABA), and jasmonic acid $(\mathrm{JA})$ is closely related to agricultural production and the green revolution technology [4]. Phytohormones are usually present at extremely low concentrations, instability, and spatio-temporal distribution in certain plant organs $[5,6]$. To elucidate the regulatory mechanisms of phytohormones on plant growth and development, highly sensitive profiling phytohormones in specific organs such as seed has received persistent attention.

Oil crops contribute a total of $93 \%$ to the vegetable oils for human consumption worldwide [7]. Vegetable oils are the foremost among all oil products exhibiting specific beneficial and functional properties towards human [8]. In oil crops, accumulating research reported that the phytohormones exhibit a significant effect on seed germination, seedling growth, and yield [9-11], thus the quantification of the phytohormones is critical for the underlying regulation mechanism. However, the analysis of phytohormones in oilseeds matrices is yet a challenging issue, because of the inherent complexity of the matrix. lipid matrix interferences in oilseeds make it difficult for quantification of phytohormones due to the high oil content. Lipids are difficult to avoid the co-extraction with the phytohormones in organic solvents during the preparing process, the detection sensitivity of the target analytes will be significantly reduced due to the existence of lipids[8]. The structural and chemical diversity of phytohormones make it challenge to simultaneous determination of multiple phytohormones. Therefore, a highly sensitive and reliable quantification method to determine multiple phytohormones in oilseeds rich in fatty acids is extremely demanding.

Nowadays, the ultra-high performance liquid chromatography-tandem mass spectrometry (UPLC-MS/MS) is being widely acknowledged for analyzing the phytohormones [12]. Chemical-derivatization assisted LC-MS methods have been demonstrated to be powerful tools for sensitive detection of trace phytohormones with poor MS response in negative mode $[13,14]$. Although derivatization reactions are tedious and time-consuming, various derivatization reactions have been used to enhance both the ionization efficiency and detection sensitivity of the phytohormones. Many of the reported derivatization reactions of acid phytohormones mostly occur in an organic medium $[15,16]$. GAs, IAA, ABA, and JA contain carboxyl groups which could derivatizate by reagents with a quaternary ammonium group such as $\mathrm{N}$-(3-dimethylaminopropyl)-N'-ethylcarbodiimide hydrochloride (EDC), what's more, the EDC-derived phytohormones could be generated in an aqueous medium [17]. The implementation of in situ aqueous derivatization coupled with the sample pre-treatment technique for phytohormones might simplify the analytical methods. The combination of extraction and in situ derivatization is considered as a promising sample preparation method.

For the oilseeds, samples were often extracted and purified in multiple steps during the pre-treatment process to reduce the interference of lipid matrix [18]. In recent years, the matrix dispersion technology was developed for the treatment of fatty solid samples by mixing with clean-up sorbents [19]. The common dispersive sorbents used in fatty matrices include C18, primary secondary amine (PSA), and florisil [20]. Nowadays, magnetic dispersion solidphase extraction (MD-SPE) is being applied to the plant samples for quantification of phytohormones [17, 21]. In brief, MD-SPE is more convenient than the conventional SPE due to the advantages of simplicity, time saving, and excellent adsorption efficiency [22]. Therefore, the highly selective and functional decorated adsorbent has attracted more attention to enrich the phytohormones. $\mathrm{Ti}_{3} \mathrm{C}_{2} \mathrm{MXene}$ exerts a two-dimensional micro-crack structure allowing large specific surface area, high porosity, and good stability [23]. It have demonstrated that $\mathrm{Ti}_{3} \mathrm{C}_{2}$ exhibits a greater ability to adsorb a variety of environmental pollutants, including organic dyes, heavy metal ions, and gas molecules [24, 25]. $\beta$-Cyclodextrin ( $\beta$-CD) is a type of oligosaccharide having a unique appearance of hydrophilic and inner cavity hydrophobic cup structure. The $\beta$-CD could selectively bind phytohormones with the special hydrophobic cavity [21]. The magnetic $\mathrm{Ti}_{3} \mathrm{C}_{2}$ composite conjoins the high adsorption capacity with the convenient magnetic separation. Supporting this statement, further study demonstrated that magnetic $\mathrm{Ti}_{3} \mathrm{C}_{2}$ can be modified by $\beta-C D$ and is possible to improve the selectivity of phytohormones in 
oilseeds samples. To the best of our knowledge, this is the first study reporting the use of $\mathrm{Fe}_{3} \mathrm{O}_{4} @ \mathrm{Ti}_{3} \mathrm{C}_{2} @ \beta$-CD to selective enrichment of phytohormones. However, the application of functionalized $\mathrm{Ti}_{3} \mathrm{C}_{2} \mathrm{MXene}$ for solid extraction adsorbent to the analysis of phytohormones needs to be further explored.

The present study aimed at developing a rapid, eco-friendly, and effective method based on the in situ derivatization and MD-SPE for the extraction of phytohormones in the oilseeds samples followed by LC-MS/MS determination. In this study, oilseeds samples and sorbent were ground by the matrix dispersion to degrease the fatty acids. The $\mathrm{Fe}_{3} \mathrm{O}_{4} @ \mathrm{Ti}_{3} \mathrm{C}_{2} @ \beta-\mathrm{CD}$ was prepared as the sorbent material showing good extraction efficiency for phytohormones. The extraction, purification, and derivatization were integrated into one single step by adding an EDC derivatizing agent and performed in a micro-centrifuge tube without any sample transfer. The main parameters involved were optimized. Finally, the proposed method was successfully applied to different oilseeds.

\section{Results And Discussion}

\section{Characterization of $\mathrm{Fe}_{3} \mathrm{O}_{4} @ \mathrm{Ti}_{3} \mathrm{C}_{2} @ \beta-\mathrm{CD}$ composite}

Fig. 1a illustrates the X-ray diffraction (XRD) patterns of the $\mathrm{Fe}_{3} \mathrm{O}_{4} @ \mathrm{Ti}_{3} \mathrm{C}_{2}$ and $\mathrm{Fe}_{3} \mathrm{O}_{4} @ \mathrm{Ti}_{3} \mathrm{C}_{2} @ \beta$-CD. The characteristic diffraction peaks (002) of the material were fitted well with $\mathrm{Ti}_{3} \mathrm{C}_{2}$, which was consistent with the report [26]. The characteristic diffraction peaks of Fe $\mathrm{O}_{4}$ matched well with the standard XRD data of magnetite[22]. After $\mathrm{Fe}_{3} \mathrm{O}_{4} @ \mathrm{Ti}_{3} \mathrm{C}_{2}$ was grafted with $\beta-\mathrm{CD}$, the pattern was unchanged in its peak positions, suggesting that the crystal structure of $\mathrm{Fe}_{3} \mathrm{O}_{4}$ nanoparticles was not affected by the grafted $\beta$-CD. The FT-IR of the composite material detected the relatively strong peaks of 3436 $\mathrm{cm}^{-1}, 1030 \mathrm{~cm}^{-1}$, and $584 \mathrm{~cm}^{-1}$ (as shown in Fig. $1 \mathrm{~b}$ ), which should be from the stretching vibration of $\mathrm{O}-\mathrm{H}, \mathrm{C}-\mathrm{O}$ of $\beta-\mathrm{CD}$, and Fe-O of Fe $\mathrm{O}_{4}$, respectively $[21$, 22]. Fig. $1 \mathrm{c}$ illustrates the measurement of the field-dependent magnetization by a vibrating sample magnetometer at room temperature. The significant hysteresis loops in the S-shaped curves indicate the ferromagnetic behaviors of the materials. The saturation magnetization was calculated to be 66.0 $\mathrm{emu} / \mathrm{g}$.

The microstructures of the $\mathrm{Ti}_{3} \mathrm{C}_{2}$ and $\mathrm{Fe}_{3} \mathrm{O}_{4} @ \mathrm{Ti}_{3} \mathrm{C}_{2} @ \beta$ - $\mathrm{CD}$ were characterized by the scanning electron microscopy (SEM) and the transmission electron microscopy (TEM). Fig. 2a illustrates the typical $\mathrm{Ti}_{3} \mathrm{C}_{2}$ MXene with layered structure, whereas Fig. $2 \mathrm{~b}$ displays the distribution of nanoparticles on the surface of multi-layered $\mathrm{Ti}_{3} \mathrm{C}_{2}$ MXene. As depicted in Fig. $2 c, 2 d$, the transmission electron microscopy (TEM) image of the hybrid reveals the incorporation of the $\mathrm{Fe}_{3} \mathrm{O}_{4}$ nanoparticles between the space of multi-layered $\mathrm{Ti}_{3} \mathrm{C}_{2}$. Elemental mapping can be found that $\mathrm{Fe}_{3} \mathrm{O}_{4}$ nanoparticles are homogeneously distributed on the $\mathrm{Ti}_{3} \mathrm{C}_{2}$ from element mapping of $\mathrm{Fe}$ and $\mathrm{Ti}$ (Fig. 2e).

\section{Optimization of parameters in the simultaneous derivatization and MD-SPE}

\section{Selection of the clean-up sorbents}

Lipid components are the most common coexisting matrix in the extraction phase of oilseeds. So the effects of different sorbents (C18, PSA, kieselguhr, alumina, and florisil) on extraction efficiency were investigated. As depicted in Fig. 3a, the effects of the florisil sorbent on extraction efficiency were significantly higher on the phytohormones compared to other clean-up sorbents. Florisil as matrix sorbent may be attributed to purify the oilseeds samples, also has advantageous effects on decrease the retention of targets. Thus, florisil sorbent was employed for the following experiments.

\section{Selection of extraction solvent types and volumes}

The selection of an appropriate extraction solvent can achieve higher extraction efficiency of phytohormones. In this study, four organic solvents (acetonitrile, methanol, $80 \%$ acetonitrile, and $80 \%$ methanol) were evaluated. As depicted in Fig. S1, methanol enhances the extraction efficiencies for multiple phytohormones. Hence, methanol was preferred as an appropriate extraction organic solvent. Further, the influences of the extraction solutions' volume on the phytohormones were investigated. As shown in Fig. S2, the extraction solution increased from $200 \mu \mathrm{L}$ to $400 \mu \mathrm{L}$ exhibiting a higher distribution ratio of the analytes in the organic phase, thereby decreasing the extraction efficiencies. Therefore, $200 \mu \mathrm{L}$ of methanol was considered as the extraction solution.

\section{Optimization of the amount of magnetic solid-phase extraction sorbents}

The EDC-derived phytohormones possess a positively charged quaternary ammonium group that may attract the hydroxyl groups or oxygen groups existing on the surface of $\mathrm{Ti}_{3} \mathrm{C}_{2}$ [27]. At the same time, the $\beta$-CD could selectively bind the phytohormones by molecular piston [28]. The effect of the amount of magnetic solid-phase extraction sorbents were investigated by adding different amounts $\mathrm{Fe}_{3} \mathrm{O}_{4} @ \mathrm{Ti}_{3} \mathrm{C}_{2} @ \beta$-CD. As shown in Fig 3b, the peak area of the phytohormonal derivatives increased with the change of $\mathrm{Fe}_{3} \mathrm{O}_{4} @ \mathrm{Ti}_{3} \mathrm{C}_{2} @ \beta$ - $\mathrm{CD}$ from $1 \mathrm{mg}$ to 5 mg. The increase in the adsorption capacity could attribute to the availability of a greater number of adsorption sites. Only a slight increase in the adsorption was observed when the sorbent amount exceeded $5 \mathrm{mg}$. Thus, $5 \mathrm{mg} \mathrm{Fe} \mathrm{O}_{4} / \mathrm{Ti}_{3} \mathrm{C}_{2} / \beta-\mathrm{CD}$ nan-composite was used in the following experiments.

\section{Optimization of simultaneous derivatization and magnetic solid-phase extraction time}

The extraction and in situ derivatization processes were the pivotal steps in this method. Therefore, the effect of extraction and in situ derivatization time were investigated by varying from 30 to 120 min. As shown in Fig 3c, the signals of derivatives increased with the extension of reaction time until 90 min, and then insignificant changes were observed. Therefore, 90 min was chosen to mediate the extraction and in situ derivatization. 
It should be noted that water is a strong desorption solvent in the hydrophilic retention systems [29]. Therefore, water was used as the desorption solution for the phytohormonal derivatives. The volume of the desorption water solution was further optimized. As shown in Fig S3, $50 \mu \mathrm{L}$ of desorption solution was enough for the desorption of the derivatives from the sorbent. The dilution effect of the desorption was observed when the volume of the desorption solution increased from $50 \mu \mathrm{L}$ to $100 \mu \mathrm{L}$. Hence, $50 \mu \mathrm{L}$ water was used as the desorption solution. The optimization of desorption time ranged from 10 to 30 min was performed, which indicated that 20 min was enough for efficient desorption (Fig. 3d). The mass transfer between the sorbent and acidic phytohormonnal derivatives may be completed within $20 \mathrm{~min}$. Hence, the desorption time of 20 min was selected.

\section{Method validation}

As depicted in Table 1, the calibration curves of all the analytes exhibited good linear determination coefficients $\mathrm{R}^{2}(\geq 0.9928)$. The obtained calibration curves demonstrate the excellent linearity for the range studied in this work. The LOD and LOQ values were within the range of $0.89-13.62 \mathrm{pg} / \mathrm{mL}$ and 2.99 $45.39 \mathrm{pg} / \mathrm{mL}$ for all target analytes, respectively. In Table 1, the recoveries were ranged from $80.4 \%$ to $117.7 \%$ for all target phytohormones. The RSD values of the intra-day precisions and inter-day precisions were in the range of $1.1-13.7 \%$ and $0.1-11.6 \%$, respectively. These results indicate the acceptable repeatability and reproducibility of the proposed method. A matrix-effect is considered to be a suppression or enhancement of the analyte response due to the presence of co-eluting matrix constituents during the chromatographic run [30]. Signal suppression or enhancement may exert negative or positive ME values, respectively. A ME $<-20 \%$ indicates high ion suppression whereas an ME $>20 \%$ indicates high signal enhancement effect and $-20 \%<\mathrm{ME}<20 \%$ indicates no matrix effects [31]. In this study, moderate signal suppressions $(-16.63 \%<\mathrm{ME}<17.06 \%)$ were observed for all analytes. The absolute values of the ME were significantly low due to the derivatization or the matrix clean-up of florisil adsorbent. For example, the EDC derivatization could increase the target molecules' sensitivity avoiding matrix interference [32].

\section{Appling of the proposed method for the analysis of different oilseed samples}

The validated analytical method was employed to determine the content of phytohormones in different oilseeds plants (bean, peanut, and sesame). The total fatty acid contents of different oilseeds were shown in Fig S5. The concentrations of 12 phytohormones are listed in Table 3 ranging from ND (not detected) to $1289.5 \mathrm{ng} / \mathrm{g} \mathrm{FW}$. The total content of the phytohormones in bean was higher than in peanut and in sesame, especially for ABA. High content of ABA in bean is similar with the previously report [33]. The recovery experiments were carried out and the obtained results are depicted in Table 2. These recoveries and SD indicated that the present method is suitable for the determination of phytohormones in different oilseeds plants.

\section{Comparison of the proposed method with other methods}

In Table 3, the proposed method was compared with other solid-phase extraction methods for analyzing the phytohormones in the plant from previous reports. Graphene oxide [21], $\mathrm{SiO}_{2}$ [34], and $\mathrm{TiO}_{2}$ [17] were reported as the adsorbents for phytohormones during the solid-phase extraction. The MD-SPE is more convenient than the conventional SPE cartridges due to less consumption time and organic solvent [35]. These reported methods limited the plant sample consumption between $100 \mathrm{mg}$ to $3.0 \mathrm{~g} \mathrm{FW}$ for multi-phytohormonal profiles, but more sample requirements could make it difficult to detect the minute plant organs [21,36,37]. In contrast, this method provides quantification of most major plant hormones from a single rapeseed (4-6 mg). Compared with other solid-phase extraction coupled with UPLC-MS/MS methods, the LODs of this method were lower than the LODs of previouly reported about for target phytohormones. $\mathrm{Fe}_{3} \mathrm{O}_{4} @ \mathrm{Ti}_{3} \mathrm{C}_{2} @ \beta$-CD nano-composite material and EDC derivatization contributed to the increased detection sensitivity of the methods. This simple procedure deduced the losses from transfers and may ensure extractive and reliable recoveries (80.4-117.7 \%). Hence, the proposed method has several advantages over the other reported techniques, being simple, effective, and eco-friendly.

\section{Conclusion}

In this study, the $\mathrm{Fe}_{3} \mathrm{O}_{4} / \mathrm{Ti}_{3} \mathrm{C}_{2} / \beta$-CD was successfully synthesized and developed as the magnetic solid-phase extraction adsorbents for the selective extraction of multiple gibberellins and several phytohormones. A new version of prepared method concluded that the magnetic solid-phase combined with in situ EDC derivatization is the best approach for studying the distribution of 12 phytohormones in rapeseed as it provides simplification, adequate selectivity, and sensitivity. This method was also successful for analyzing phytohormones and resolving the problems such as unstability, trace amount, and matrix interference in different oilseeds samples.

\section{Methods}

\section{Chemical and reagents}

Gibberellin $\mathrm{A}_{1}\left(\mathrm{GA}_{1}\right), \mathrm{GA}_{3}, \mathrm{GA}_{4}, \mathrm{GA}_{5}, \mathrm{GA}_{7}, \mathrm{GA}_{8}, \mathrm{GA}_{9}, \mathrm{GA}_{20}, \mathrm{GA}_{51}, \mathrm{IAA}, \mathrm{ABA}$, and JA were purchased from OlChemIm Ltd. (Olomouc, Czech Republic). [ $\left.{ }^{2} \mathrm{H}_{2}\right] \mathrm{GA} \mathrm{A}_{1}$, $\left[{ }^{2} \mathrm{H}_{2}\right] \mathrm{GA}_{4},\left[{ }^{2} \mathrm{H}_{2}\right] \mathrm{GA}_{9},\left[{ }^{2} \mathrm{H}_{6}\right] \mathrm{ABA},\left[{ }^{2} \mathrm{H}_{5}\right] \mathrm{JA}$, and $\left[{ }^{2} \mathrm{H}_{2}\right] \mathrm{IAA}$ were purchased from OlChemlm Ltd. (Olomouc, Czech Republic) and used as internal standards (ISTDs). EDC (>98.0\%) was purchased from TCI Development Co., Ltd., (Shanghai, China). Methanol ( $\geq 99.9 \%)$ and acetonitrile ( $\geq 99.9 \%)$ were purchased from Sigma-Aldrich (Sigma-Aldrich, St. Louis, USA). The matrix dispersion sorbents for experiments included kieselguhr, C18-bonded silica (C18), primary secondary amine (PSA), alumina-N, and florisil were purchased from CNW Technologies (Shanghai, China). $\mathrm{Ti}_{3} \mathrm{AlC}_{2}$ powder (> 98 wt\% purity) was obtained from 11 Technology Co., Ltd, China. Ultrapure water (resistivity $\geq 18.25 \mathrm{M} \Omega / \mathrm{cm}$ ) obtained from WaterPro water system (ULUPURE, China) was used in all experiments. Individual stock standard solutions $(1000 \mathrm{mg} / \mathrm{L})$ of each compound were prepared using methanol and stored in the refrigerator at $-20{ }^{\circ} \mathrm{C}$. 
The mixed standard solutions were stored at $4{ }^{\circ} \mathrm{C}$. EDC solutions were prepared by freshly dissolving EDC powder in the methanol. All the reagents were of analytical grades (least $98 \%$ purity).

\section{Preparation of magnetic nano-composite $\mathrm{Fe}_{3} \mathrm{O}_{4} @ \mathrm{Ti}_{3} \mathrm{C}_{2} @ \beta-\mathrm{CD}$}

Fig.4 illustrates the method of preparation of $\mathrm{Fe}_{3} \mathrm{O}_{4} @ \mathrm{Ti}_{3} \mathrm{C}_{2} @ \beta-\mathrm{CD}$ hybrid. $2 \mathrm{~g}$ of the $\mathrm{Ti}_{3} \mathrm{AlC}_{2}$ powder was immersed in $20 \mathrm{~mL}$ of hydrofluoric acid $(\mathrm{HF})$ solutions by stirring for $24 \mathrm{~h}$ at $60^{\circ} \mathrm{C}$ for complete removal of the Al layers. Then, the solution was centrifuged and rinsed several times using deionized water to remove the $\mathrm{HF}$ and until the $\mathrm{pH}$ attained 5-6. The obtained $\mathrm{Ti}_{3} \mathrm{C}_{2}$ powder was then vacuum-dried at $80^{\circ} \mathrm{C}$ for $24 \mathrm{~h}$.

$\mathrm{Fe}_{3} \mathrm{O}_{4}$ nanoparticles were synthesized according to the hydrothermal method [38]. $100 \mathrm{mg}$ of $\mathrm{Ti}_{3} \mathrm{C}_{2}$ power and 50 mg of Fe $\mathrm{O}_{4}$ nanoparticle were ultrasonically dispersed in $80 \mathrm{~mL}$ and $20 \mathrm{~mL}$ of deionized water for $30 \mathrm{~min}$, respectively. Both were mixed by ultrasonification for 120 min and argon shield. Then the suspension was filtrated to obtain the $\mathrm{Fe}_{3} \mathrm{O}_{4} @ \mathrm{Ti}_{3} \mathrm{C}_{2}$ hybrid and followed drying in a vacuum at $50{ }^{\circ} \mathrm{C}$ for $24 \mathrm{~h}$.

$\mathrm{Fe}_{3} \mathrm{O}_{4} @ \mathrm{Ti}_{3} \mathrm{C}_{2}$ composite loaded with $\beta-\mathrm{CD}, 100 \mathrm{mg}$ of $\mathrm{Fe}_{3} \mathrm{O}_{4} @ \mathrm{Ti}_{3} \mathrm{C}_{2}$, and $2.0 \mathrm{~g}$ of $\beta-\mathrm{CD}$ were dispersed into 60 mL deoxygenated water by ultrasonification for $20 \mathrm{~min}$. Then, the reaction system was kept in an oil bath at $60{ }^{\circ} \mathrm{C}$ for $4 \mathrm{~h}$ and argon shield. Finally, the obtained $\mathrm{Fe}_{3} \mathrm{O}_{4} @ \mathrm{Ti}_{3} \mathrm{C}_{2} @ \beta-\mathrm{CD}$ was washed with deionized water and then vacuum-dried at $50^{\circ} \mathrm{C}$ for $24 \mathrm{~h}$.

\section{Plant materials}

Seeds of Brassica napus (rapeseed), Sesamum indicum (sesame), Glycine max (bean), and Arachis hypogaea (peanut) were obtained from Hunan Branch of National Center of Oilseed Crops Improvement (Changsha, China). The different seeds of oil crops were harvested, frozen in liquid nitrogen, and stored at $-80{ }^{\circ} \mathrm{C}$ until further analyzed.

\section{Sample preparation and in situ derivatization}

Single fresh rapeseed seed was mixed with $2 \mathrm{mg}$ clean-up sorbents and beads into a $2.0 \mathrm{~mL}$ microcentrifuge tube. The mixture was immediately ground with one cold $\mathrm{ZrO}_{2}$ mill ball by ball milling (TissueLyser II, QIAGEN, Germany) at $20 \mathrm{~Hz}$ for $4 \mathrm{~min}$. Then, the internal standards (IS) were added into the tube. The ground sample was extracted with $200 \mu \mathrm{L}$ of cold methanol and vortexed at $4{ }^{\circ} \mathrm{C}$ for $30 \mathrm{~S}$, then left to stand at $4{ }^{\circ} \mathrm{C}$ for $12 \mathrm{~h}$. The supernatant was collected by centrifugation at $10000 \times \mathrm{g}$ for $5 \mathrm{~min}$ and transferred to a $1.5 \mathrm{~mL}$ microcentrifuge tube. The supernatant was added with $5 \mathrm{mg}$ magnetic nanoparticles and $50 \mu \mathrm{L}$ of derivatizing agent (20 mM EDC), then incubated at $40{ }^{\circ} \mathrm{C}$ for $90 \mathrm{~min}$. Both the extraction and derivatization were completed at one step. The nanoparticles were collected from the suspension by magnetic separation and re-dispersed by $50 \mu \mathrm{L}$ of $5 \%$ menthol. After desorption for 20 min, the eluent was collected and determined by UHPLC-ESI-MS/MS. The general process of sample pre-treatment is illustrated in Fig.4.

\section{Instruments and analytical conditions}

The UPLC-MS/MS was equipped with an Agilent 1290 series (Agilent Technologies, USA) and Agilent 6460 triple quadruple mass spectrometer (Agilent Technologies, USA). The analytes were separated on a Waters ACQUITY UPLC HSS T3 column (100 mm $\times 2.1 \mu \mathrm{m})$. The optimized separation conditions were as follows: the column oven temperature was kept at $40{ }^{\circ} \mathrm{C}$, and the sample injection volume was $10 \mu \mathrm{L}$, the flow rate of the mobile phase was 0.3 $\mathrm{mL} / \mathrm{min}$. The elution gradient program of the positive ion mode was performed, as depicted in Table S1.

The multiple reaction monitoring (MRM) was employed for the quantitative analysis of the targeted compounds. Nitrogen gas was used as the drying and collision gas. The ionization source conditions were as follows: the flow rate of the nebulizer gas was $8 \mathrm{~L} / \mathrm{min}$, the source temperature of the mass spectrometer was $300{ }^{\circ} \mathrm{C}$, the nebulizer pressure was $50 \mathrm{psi}$, and the capillary voltage was $3500 \mathrm{~V}$. The details of the EDC-derived phytohormones and their optimized MRM parameters are listed in Table 4. The MRM chromatograms of the target EDC-derived phytohormones were shown in Fig. 5. The MRM chromatograms with subsection of target phytohormone derivates in a single rapeseed were shown in Fig. 6.

\section{Method validation}

To validate the developed method, the linearity, limit of detection (LOD), limit of quantification (LOQ), accuracy, precision, and matrix effect (ME) were investigated. Calibration samples at 6 concentrations $(0.01,0.05,0.10,0.50,1.0,10 \mathrm{ng} / \mathrm{mL}$ of GAs derivates, 0.10, 0.50, 1.0, 5.0, 10, 100 ng/mL of IAA, ABA, JA derivates) with a fixed concentration of IS $\left(\left[{ }^{2} \mathrm{H}_{2}\right] \mathrm{GA}, 0.1 \mathrm{ng} / \mathrm{g},\left[{ }^{2} \mathrm{H}_{2}\right] \mathrm{GA}{ }_{4} 0.1 \mathrm{ng} / \mathrm{g},\left[{ }^{2} \mathrm{H}_{2}\right] \mathrm{GA}, 0.1 \mathrm{ng} / \mathrm{g},\left[{ }^{2} \mathrm{H}_{2}\right] \mathrm{IAA} 0.2 \mathrm{ng} / \mathrm{g},\left[{ }^{2} \mathrm{H}_{6}\right] \mathrm{ABA} 1 \mathrm{ng} / \mathrm{g}\right.$, and $\left[{ }^{2} \mathrm{H}_{6}\right] \mathrm{JA}$ $0.1 \mathrm{ng} / \mathrm{g}$ for each). The LOD values were calculated as 3 times of the standard deviation of 11 replicates for rapeseed samples spiked at the $0.01 \mathrm{ng} / \mathrm{mL}$ level for GAs, $1 \mathrm{ng} / \mathrm{mL}$ level for IAA, ABA, and JA, respectively. LOQ values were calculated as 10 times of the standard deviation of 11 replicates for rapeseed samples spiked at the same level as used in calculating the LOD values.

Accuracy was evaluated by the recovery of each target analyte at low, medium, and high levels, respectively. The precision was investigated by the intraday precision (repeatability) and inter-day precision (reproducibility). The intra-day precision was evaluated by analyzing 7 replicates on the same day while the inter-day precision was carried out for 3 consecutive days (7 replicates per day). During the trace analyses with a complex matrix, the ME usually occurs and its percentage can be calculated as per the equation below:

$\mathrm{ME} \%=\left(\mathrm{A}_{\text {extract }} / \mathrm{A}_{\text {solvent }}-1\right) \times 100$ 
where, $A_{\text {extract }}$ stands for the slope of matrix-match calibration curves, $A_{\text {solvent }}$ stands for the slope of solvent calibration curves.

\section{Declarations}

\section{Authors' contributions}

ZL designed the work; XW performed the experiments; $Z \mathrm{~L}, \mathrm{XW}$ and $\mathrm{XL}$ processed the experiment data; $\mathrm{ZL}$ wrote the manuscript; $\mathrm{LX}$ and $\mathrm{RW}$ revised and supervised the manuscript. ZL and MX contributed equally to this work. All authors read and approved the final manuscript.

\section{Acknowledgements}

Not applicable.

\section{Competing interests}

The authors declare that they have no competing interests.

\section{Availability of data and materials}

The scripts and datasets used and/or analyzed during the current study are available from the corresponding author on reasonable request.

\section{Consent for publication}

Not applicable.

\section{Ethics approval and consent to participate}

Not applicable.

\section{Funding}

This study was supported by the National Natural Science Foundation of China (90817101 and 30670190) and Scientific Research Fund of Hunan Provincial Education Department (16K042 and 18C0130).

\section{References}

1. Mikihisa U, Atsushi H, Satoko Y, Kohki A, Tomotsugu A, Noriko TK, Hiroshi M, Yuji K, Ken S, Koichi Y. Inhibition of shoot branching by new terpenoid plant hormones. Nature. 2008;455(7210):195-200.

2. Fuentes S, Ljung K, Sorefan K, Alvey E, Harberd NP, Ostergaard L. Fruit growth in Arabidopsis occurs via DELLA-dependent and DELLA-independent gibberellin responses. Plant Cell. 2012;24(10):3982-3996.

3. Chen ML, Huang YQ, Liu JQ, Yuan BF, Feng YQ. Highly sensitive profiling assay of acidic plant hormones using a novel mass probe by capillary electrophoresis-time of flight-mass spectrometry. J Chromatogr B, Analyt Technol Biomed Life Sci. 2011;879(13-14):938-944.

4. Kwon CT, Paek NC: Gibberellic acid. a key phytohormone for spikelet fertility in rice grain production. Int J Mol Sci. 2016;17(5).

5. Simura J, Antoniadi I, Siroka J, Tarkowska D, Strnad M, Ljung K, Novak O. Plant hormonomics: multiple phytohormone profiling by targeted metabolomics. Plant Physiol. 2018;177(2):476-489.

6. Cai WJ, Ye TT, Wang Q, Cai BD, Feng YQ. A rapid approach to investigate spatiotemporal distribution of phytohormones in rice. Plant Methods. 2016;12:47.

7. Elbeltagi HES, Mohamed AA. Variations in fatty acid composition, glucosinolate profile and some phytochemical contents in selected oil seed rape (Brassica napus L.) cultivars. Grasas Aceites. 2010;61(2):143-150.

8. Gilbert-Lopez B, Garcia-Reyes JF, Molina-Diaz A. Sample treatment and determination of pesticide residues in fatty vegetable matrices: a review. Talanta. 2009;79(2):109-128.

9. Li Z, Lu GY, Zhang XK, Zou CS, Cheng Y, Zheng PY. Improving drought tolerance of germinating seeds by exogenous application of gibberellic acid (GA3) in rapeseed (Brassica napus L.). Seed Sci Technol. 2010;38(2):432-440.

10. Santos HO, Von Pinho EV, Von Pinho IV, Dutra SM, Andrade T, Guimarães RM. Physiological quality and gene expression during the development of habanero pepper (Capsicum chinense Jacquin) seeds. Genet Mol Res. 2015;14(2):5085-5098.

11. Yakubu H, Izge AU, Hussaini MA, Jibrin JM, Bello OG, Isyaku MS: Varietal response and gibberellic acid concentrations on yield and yield traits of groundnut (Arachis hypogaea L.) under wet and dry conditions. Acad J Agr Res. 2013;1(1): 001-008.

12. Pan XQ, Ruth, Welti R, Wang XM. Quantitative analysis of major plant hormones in crude plant extracts by high-performance liquid chromatographymass spectrometry. Nat Protoc. 2010;5(6):986-992.

13. Li D, Guo Z, Chen Y. Direct derivatization and quantitation of ultra-trace gibberellins in sub-milligram fresh plant organs. Mol Plant. 2016;9(1):175-177. 
14. Yu L, Ding J, Wang YL, Liu P, Feng YQ. 4-Phenylaminomethyl-benzeneboric acid modified tip extraction for determination of brassinosteroids in plant tissues by dtable isotope labeling-liquid chromatography-mass spectrometry. Anal Chem. 2015;88(2):1286-1293.

15. Xiao HM, Cai WJ, Ye TT, Ding J, Feng YQ. Spatio-temporal profiling of abscisic acid, indoleacetic acid and jasmonic acid in single rice seed during seed germination. Anal Chim Acta. 2018;1031:119-127.

16. Deng T, Wu D, Duan C, Yan X, Du Y, Zou J, Guan Y. Spatial profiling of gibberellins in a single leaf based on microscale matrix solid-phase dispersion and precolumn derivatization coupled with ultraperformance liquid chromatography-tandem mass spectrometry. Anal Chem. 2017;89(17):9537-9543.

17. Liu JF, Ding J, Yuan BF, Feng YQ. Magnetic solid phase extraction coupled with in situ derivatization for the highly sensitive determination of acidic phytohormones in rice leaves by UPLC-MS/MS. The Analyst. 2014;139(21):5605-5613.

18. Ma X, Li H, Zhang J, Huang W, Han J, Ge Y, Sun J, Chen Y. Comprehensive quantification of sesame allergens in processed food using liquid chromatography-tandem mass spectrometry. Food Control. 2020;107:106744.

19. Wang Y, Sun Y, Xu B, Li X, Wang X, Zhang H, Song D. Matrix solid-phase dispersion coupled with magnetic ionic liquid dispersive liquid-liquid microextraction for the determination of triazine herbicides in oilseeds. Anal Chim Acta. 2015;888:67-74.

20. López-Blanco R, Nortes-Méndez R, Robles-Molina J, Moreno-González D, Gilbert-López B, García-Reyes JF, Molina-Díaz A. Evaluation of different cleanup sorbents for multiresidue pesticide analysis in fatty vegetable matrices by liquid chromatography tandem mass spectrometry . $\mathrm{J}$ Chromatogr A. 2016;1456:89-104.

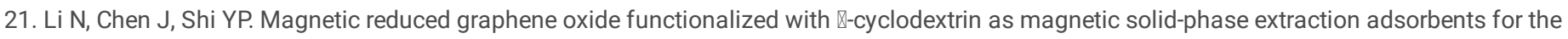
determination of phytohormones in tomatoes coupled with high performance liquid chromatography. J Chromatogr A. 2016;1441:24-33.

22. Luo Z, Li H, Yang Y, Lin H, Yang Z. Adsorption of 17a-ethinylestradiol from aqueous solution onto a reduced graphene oxide-magnetic composite. J Taiwan Inst Chem E. 2017;80:797-804.

23. Sinha A, Dhanjai, Zhao H, Huang Y, Lu X, Chen J, Jain R. MXene: An emerging material for sensing and biosensing. Trac-Trends Anal Chem. 2018;105:424-435.

24. Zhang Y, Wang aL, Zhanga bN, Zhoua Z. Adsorptive environmental applications of MXene nanomaterials: a review. Rsc Advances. 2018;8(36):1989519905.

25. Jun B-M, Kim S, Heo J, Park CM, Her N, Jang M, Huang Y, Han J, Yoon Y. Review of MXenes as new nanomaterials for energy storage/delivery and selected environmental applications. Nano Res. 2018;12(3):471-487.

26. Wang F, Yang C, Duan M, Tang Y, Zhu J. $\mathrm{TiO}_{2}$ nanoparticle modified organ-like $\mathrm{Ti}_{3} \mathrm{C}_{2}$ MXene nanocomposite encapsulating hemoglobin for a mediatorfree biosensor with excellent performances. Biosens Bioelectron. 2015;74:1022-1028.

27. Berdiyorov G. Effect of lithium and sodium ion adsorption on the electronic transport properties of $\mathrm{Ti}_{3} \mathrm{C}_{2}$ MXene. Appl Surf Sci. 2015;359:153-157.

28. Filho CMC, Bueno PVA, Matsushita AFY, Rubira AF, Muniz EC, Dures L, Murtinho DMB, Valente AJM. Synthesis, characterization and sorption studies of aromatic compounds by hydrogels of chitosan blended with $\beta$-cyclodextrin- and PVA-functionalized pectin. Rsc Advances. 2018;8.

29. Wang F, Yang F, Tian Y, Liu J, Shen J, Bai Q. Studies on the retention mechanism of solutes in hydrophilic interaction chromatography using stoichiometric displacement theory I. The linear relationship of Igk'vs. Ig [H $\mathrm{H}_{2} \mathrm{O}$. Talanta. 2018;176:499-508.

30. Arimboor R, Menon K, Babu N, Chandran H. A Modified QuEChERS Extraction and LC-MS/MS Method for the Determination of Pesticide Residues in Curry Leaves (Murraya koenigii). Current Chromatogra. 2019;6(1):30-41.

31. Luo Z, Lu J, Li H, Tu Y, Wan Y, Yang Z. Air-assisted liquid-liquid microextraction integrated with QuEChERS for determining endocrine-disrupting compounds in fish by high-performance liquid chromatography-tandem mass spectrometry. Food Chem. 2018;260:174-182.

32. Toyo'oka T. LC-MS determination of bioactive molecules based upon stable isotope-coded derivatization method. J Pharm Biomed Anal. 2012;69:174184.

33. Farhangi-Abriz S, Torabian S. Biochar increased plant growth-promoting hormones and helped to alleviates salt stress in common bean seedlings. J Plant Growth Regul. 2017;37(2):591-601.

34. Zhang X, Niu J, Zhang X, Xiao R, Lu M, Cai Z. Graphene oxide-SiO ${ }_{2}$ nanocomposite as the adsorbent for extraction and preconcentration of plant hormones for HPLC analysis. J chromatogra B. 2017;1046:58-64.

35. Cui K, Lin Y, Zhou X, Li S, Liu H, Zeng F, Zhu F, Ouyang G, Zeng Z. Comparison of sample pretreatment methods for the determination of multiple phytohormones in plant samples by liquid chromatography-electrospray ionization-tandem mass spectrometry. Microchem J. 2015;121:25-31.

36. Luo XT, Cai BD, Chen X, Feng YQ. Improved methodology for analysis of multiple phytohormones using sequential magnetic solid-phase extraction coupled with liquid chromatography-tandem mass spectrometry. Anal Chim Acta. 2017;983:112-120.

37. Cai BD, Yin J, Hao YH, Li YN, Yuan BF, Feng YQ. Profiling of phytohormones in rice under elevated cadmium concentration levels by magnetic solidphase extraction coupled with liquid chromatography tandem mass spectrometry. J Chromatogr A. 2015;1406:78-86.

38. Cui K, Lin Y, Xi Z, Li S, Hong L, Feng Z, Fang Z, Ouyang G, Zeng Z. Comparison of sample pretreatment methods for the determination of multiple phytohormones in plant samples by liquid chromatography-electrospray ionization-tandem mass spectrometry. Microchem J. 2015;121:25-31.

\section{Tables}


Table 1: Results of the method performance and validation study

\begin{tabular}{|c|c|c|c|c|c|c|c|c|c|c|c|c|c|c|}
\hline \multirow[t]{2}{*}{ Analytes } & \multirow{2}{*}{$\begin{array}{l}\text { Linear } \\
\text { range } \\
(\mathrm{ng} / \mathrm{mL})\end{array}$} & \multirow[t]{2}{*}{$\mathrm{R}^{2}$} & \multirow[t]{2}{*}{$\begin{array}{l}\mathrm{LOD}^{\mathrm{a}} \\
(\mathrm{pg} / \mathrm{mL})\end{array}$} & \multirow[t]{2}{*}{$\begin{array}{l}\mathrm{LOQ}^{\mathrm{b}} \\
(\mathrm{pg} / \mathrm{mL})\end{array}$} & \multicolumn{3}{|c|}{ Intra-day precision $(\%)^{c}$} & \multicolumn{3}{|c|}{$\begin{array}{l}\text { Inter-day precision } \\
(\%)^{c}\end{array}$} & \multicolumn{3}{|c|}{ Recoveries(\%,n=3) } & \multirow[t]{2}{*}{$\mathrm{ME}^{\mathrm{d}} \otimes \% \otimes$} \\
\hline & & & & & Low & Medium & High & Low & Medium & High & Low & Medium & High & \\
\hline $\mathrm{GA}_{1}$ & $0.01-10$ & 0.9989 & 0.89 & 2.99 & 7.1 & 8.2 & 1.5 & 11.6 & 0.7 & 5.4 & 104.0 & 90.4 & 108.5 & -16.63 \\
\hline $\mathrm{GA}_{3}$ & $0.01-10$ & 0.9994 & 3.91 & 13.05 & 8.0 & 9.8 & 2.0 & 8.7 & 4.7 & 5.7 & 105.0 & 101.2 & 97.7 & -5.21 \\
\hline $\mathrm{GA}_{4}$ & $0.01-10$ & 0.9993 & 10.52 & 35.08 & 7.1 & 3.5 & 10.1 & 4.0 & 3.9 & 4.8 & 115.1 & 117.7 & 99.8 & 17.06 \\
\hline $\mathrm{GA}_{5}$ & $0.01-10$ & 0.9987 & 5.70 & 19.00 & 2.0 & 1.5 & 6.7 & 11.2 & 4.3 & 3.4 & 85.3 & 103.6 & 104.1 & 15.33 \\
\hline $\mathrm{GA}_{7}$ & $0.01-10$ & 0.9996 & 12.62 & 42.09 & 10.4 & 12.3 & 6.2 & 4.9 & 9.2 & 6.7 & 95.5 & 94.3 & 88.4 & -15.80 \\
\hline $\mathrm{GA}_{8}$ & $0.01-10$ & 0.9928 & 5.37 & 17.90 & 13.7 & 3.0 & 3.4 & 2.3 & 7.3 & 3.3 & 112.1 & 99.4 & 104.3 & 4.17 \\
\hline $\mathrm{GA}_{9}$ & $0.01-10$ & 0.9993 & 1.89 & 6.30 & 1.2 & 2.9 & 11.7 & 5.0 & 7.8 & 4.6 & 111.8 & 99.5 & 91.5 & 1.18 \\
\hline $\mathrm{GA}_{20}$ & $0.01-10$ & 0.9977 & 7.80 & 26.02 & 7.3 & 5.7 & 10.1 & 6.4 & 5.1 & 0.1 & 94.7 & 110.8 & 109.7 & 0.72 \\
\hline $\mathrm{GA}_{51}$ & $0.01-10$ & 0.9989 & 0.65 & 2.18 & 3.4 & 1.1 & 11.4 & 6.4 & 7.9 & 2.9 & 80.4 & 98.5 & 87.2 & -2.72 \\
\hline ABA & $0.1-100$ & 0.9991 & 7.59 & 25.31 & 9.5 & 15.1 & 2.5 & 9.7 & 7.4 & 9.1 & 108.6 & 89.3 & 92.1 & 0.29 \\
\hline JA & $0.1-100$ & 0.9991 & 2.31 & 7.70 & 8.9 & 9.7 & 5.2 & 10.8 & 7.8 & 1.7 & 92.2 & 102.7 & 100.9 & -4.83 \\
\hline IAA & $0.1-100$ & 0.9996 & 13.62 & 45.39 & 13.5 & 5.4 & 5.0 & 2.2 & 3.7 & 11.0 & 91.6 & 107.2 & 102.5 & 2.14 \\
\hline
\end{tabular}

a LOD: limit of detection;

b LOQ: Iimit of quantification;

${ }^{c}$ Phytohormones standards were spiked in rapeseed at three different concentrations $(2,10,20 \mathrm{ng} / \mathrm{g} \mathrm{FW}$ for GA $\mathrm{s}, 10,20,100 \mathrm{ng} / \mathrm{g}$ FW for ABA, JA, IAA);

${ }^{\mathrm{d}}$ ME: matrix effect.

Table 2: Results (means \pm standard deviation) obtained for the phytohormones detection and recovery in different oilseeds

\begin{tabular}{|c|c|c|c|c|c|c|}
\hline \multirow[t]{2}{*}{ Analytes } & \multicolumn{2}{|l|}{ Bean } & \multicolumn{2}{|l|}{ Peanut } & \multicolumn{2}{|l|}{ Sesame } \\
\hline & Determined (ng/g) & Recovery (\%) ${ }^{a}$ & Determined (ng/g) & Recovery (\%) & Determined (ng/g) & Recovery (\%) \\
\hline $\mathrm{GA}_{1}$ & $4.5 \pm 0.4$ & $103.2 \pm 5.2$ & $10.2 \pm 0.6$ & $111.1 \pm 5.0$ & ND & $102.1 \pm 9.7$ \\
\hline $\mathrm{GA}_{3}$ & ND & $100.4 \pm 10.6$ & $28.2 \pm 2.0$ & $102.1 \pm 5.2$ & ND & $101.8 \pm 6.1$ \\
\hline $\mathrm{GA}_{4}$ & $9.3 \pm 0.8$ & $114.3 \pm 1.6$ & $7.3 \pm 0.3$ & $110.8 \pm 0.8$ & $5.3 \pm 0.7$ & $110.9 \pm 5.9$ \\
\hline $\mathrm{GA}_{5}$ & ND & $104.9 \pm 6.8$ & $17.6 \pm 1.2$ & $101.2 \pm 8.3$ & ND & $109.0 \pm 0.6$ \\
\hline $\mathrm{GA}_{7}$ & ND & $94.3 \pm 1.1$ & ND & $92.5 \pm 4.8$ & ND & $109.1 \pm 10.3$ \\
\hline $\mathrm{GA}_{8}$ & ND & $97.5 \pm 6.3$ & $28.2 \pm 1.6$ & $109.5 \pm 6.1$ & ND & $120.2 \pm 2.0$ \\
\hline $\mathrm{GA}_{9}$ & ND & $80.4 \pm 9.2$ & $4.6 \pm 0.2$ & $92.0 \pm 2.4$ & ND & $81.3 \pm 3.4$ \\
\hline $\mathrm{GA}_{20}$ & $16.9 \pm 2.3$ & $96.1 \pm 1.5$ & $28.6 \pm 0.9$ & $112.8 \pm 6.5$ & ND & $118.4 \pm 2.2$ \\
\hline $\mathrm{GA}_{51}$ & ND & $89.5 \pm 0.3$ & ND & $110.0 \pm 0.7$ & ND & $84.8 \pm 2.3$ \\
\hline ABA & $1289.5 \pm 6.1$ & $108.0 \pm 7.7$ & $342.9 \pm 11.7$ & $86.3 \pm 3.5$ & ND & $99.7 \pm 8.7$ \\
\hline JA & ND & $116.4 \pm 0.7$ & ND & $114.8 \pm 3.0$ & ND & $107.3 \pm 5.1$ \\
\hline IAA & $10.9 \pm 0.6$ & $105.4 \pm 7.4$ & ND & $106.9 \pm 2.2$ & $20.1 \pm 1.3$ & $90.3 \pm 4.4$ \\
\hline
\end{tabular}

ND: not detected; 
a : the recovery was calculated at the spiked of $20 \mathrm{ng} / \mathrm{g}$ for $\mathrm{GAs}, 100 \mathrm{ng} / \mathrm{g}$ for $\mathrm{ABA}, \mathrm{JA}$, and IAA.

Table 3: Comparison of the solid phase extraction method with other methods of the phytohormones

\begin{tabular}{|c|c|c|c|c|c|c|c|}
\hline Sample & Analytes & $\begin{array}{l}\text { Solid phase extraction } \\
\text { adsorbent }\end{array}$ & Derivatization & Method & LOD & $\begin{array}{l}\text { Recovery } \\
(\%)\end{array}$ & Reference \\
\hline $\begin{array}{l}1.0 \mathrm{~g} \text { oilseed } \\
\text { rape leaves }\end{array}$ & $\begin{array}{l}\text { IAA, ABA, SA, JA, GAs, } \\
\text { CKs, and 6-BA }\end{array}$ & Oasis MCX cartridges & - & $\begin{array}{l}\text { HPLC- } \\
\text { MS/MS }\end{array}$ & $\begin{array}{l}1.3-21.0 \\
\mathrm{pg} / \mathrm{mL}\end{array}$ & $\begin{array}{l}75.1- \\
113 \%\end{array}$ & [38] \\
\hline $100 \mathrm{mg}$ flower & $\begin{array}{l}\text { IAA, ABA, JA, } 4 \text { GAs, } 3 \\
\text { BRs, and } 6 \text { CKs }\end{array}$ & $\begin{array}{l}\mathrm{Fe}_{3} \mathrm{O}_{4} @ \mathrm{SiO}_{2} @ \text { Poly(DMAPBA- } \\
\text { co-EGDMA) }\end{array}$ & - & $\begin{array}{l}\text { UHPLC- } \\
\text { MS/MS }\end{array}$ & $\begin{array}{l}1.9-59.6 \\
\mathrm{pg} / \mathrm{mL}\end{array}$ & $\begin{array}{l}85.0- \\
116.2 \%\end{array}$ & [36] \\
\hline $\begin{array}{l}300 \mathrm{mg} \\
\text { Arabidopsis }\end{array}$ & $\mathrm{IAA}, \mathrm{ABA}$ & $\mathrm{SiO}_{2} @ \mathrm{GO}$ & - & HPLC & $\begin{array}{l}30-50 \\
\mathrm{pg} / \mathrm{mL}\end{array}$ & $\begin{array}{l}91.8- \\
118.4 \%\end{array}$ & [34] \\
\hline $3.0 \mathrm{~g}$ tomato & NAA, 2-NOA & $\mathrm{Fe}_{3} \mathrm{O}_{4} / \mathrm{rGO} @ \beta-\mathrm{CD}$ & - & $\begin{array}{l}\text { HPLC- } \\
\text { MS/MS }\end{array}$ & $0.67 \mathrm{ng} / \mathrm{g}$ & $\begin{array}{l}91.5- \\
95.9 \%\end{array}$ & [21] \\
\hline $\begin{array}{l}100 \mathrm{mg} \text { rice } \\
\text { seeds }\end{array}$ & $\begin{array}{l}8 \mathrm{CKs}, \\
\text { IAA, ABA, JA, and } 10 \\
\text { GAs }\end{array}$ & $\mathrm{Fe}_{3} \mathrm{O}_{4} @ \mathrm{TiO}_{2}$ & - & $\begin{array}{l}\text { UHPLC- } \\
\text { MS/MS }\end{array}$ & $\begin{array}{l}0.01-1.99 \\
\text { fmol }\end{array}$ & $\begin{array}{l}86.8- \\
118.1 \%\end{array}$ & [37] \\
\hline $\begin{array}{l}100 \mathrm{mg} \text { rice } \\
\text { leaves }\end{array}$ & $\mathrm{GA}_{\mathrm{s}}, \mathrm{JA}, \mathrm{IAA}, \mathrm{ABA}$ & $\begin{array}{l}\mathrm{TiO}_{2} / \text { magnetic hollow } \\
\text { mesoporous silica sphere }\end{array}$ & BTA & $\begin{array}{l}\text { UHPLC- } \\
\text { MS/MS }\end{array}$ & $\begin{array}{l}1.03-91.21 \\
\mathrm{pg} / \mathrm{mL}\end{array}$ & $\begin{array}{l}71.6- \\
112.8 \%\end{array}$ & [17] \\
\hline $5 \mathrm{mg}$ oilseeds & $9 \mathrm{GAs}, \mathrm{IAA}, \mathrm{JA}, \mathrm{ABA}$ & $\mathrm{Fe}_{3} \mathrm{O}_{4} / \mathrm{Ti}_{3} \mathrm{C}_{2} / \beta-\mathrm{CD}$ & $\begin{array}{l}\text { In situ EDC } \\
\text { derivatization }\end{array}$ & $\begin{array}{l}\text { UHPLC- } \\
\text { MS/MS }\end{array}$ & $\begin{array}{l}0.89-13.62 \\
\mathrm{pg} / \mathrm{mL}\end{array}$ & $\begin{array}{l}80.4- \\
117.7 \%\end{array}$ & $\begin{array}{l}\text { This } \\
\text { method }\end{array}$ \\
\hline
\end{tabular}

NAA: 1-naphthalene acetic acid; 2-NOA: 2-naphthoxyacetic acid; GO: graphene oxide, BTA: 13-bromoactonyltrimethylammonium bromide, EDC: N-(3dimethylaminopropyl)-N'-ethylcarbodiimide. 
Table 4: Details of the EDC-derived acidic phytohormones and their MRM parameters under positive ionization mode

\begin{tabular}{|c|c|c|c|c|c|c|}
\hline Analytes & Internal standards & $\begin{array}{l}\text { RT } \\
\bigotimes \min \rrbracket\end{array}$ & $\begin{array}{l}\text { Parent ion } \\
(\mathrm{m} / \mathrm{z})\end{array}$ & $\begin{array}{l}\text { Product ion } \\
(\mathrm{m} / \mathrm{z})\end{array}$ & $\begin{array}{l}\text { Collision energy } \\
(\mathrm{eV})\end{array}$ & $\begin{array}{l}\text { Fragmentor } \\
\text { (V) }\end{array}$ \\
\hline $\mathrm{GA}_{1}-\mathrm{EDC}$ & {$\left[{ }^{2} \mathrm{H}_{2}\right] \mathrm{GA}_{1}$} & 7.6 & 504.2 & 433.3/388.8 & $25 / 30$ & 130 \\
\hline $\mathrm{GA}_{3}-\mathrm{EDC}$ & {$\left[{ }^{2} \mathrm{H}_{2}\right] \mathrm{GA}_{1}$} & 7.4 & 502.2 & $431.3 / 386.2$ & $20 / 28$ & 135 \\
\hline $\mathrm{GA}_{4}-\mathrm{EDC}$ & {$\left[{ }^{2} \mathrm{H}_{2}\right] \mathrm{GA}_{4}$} & 17.5 & 488.3 & $417.4 / 372.2$ & $28 / 35$ & 135 \\
\hline $\mathrm{GA}_{5}-\mathrm{EDC}$ & {$\left[{ }^{2} \mathrm{H}_{2}\right] \mathrm{GA}_{4}$} & 12.1 & 486.3 & $415.0 / 370.1$ & $20 / 27$ & 135 \\
\hline $\mathrm{GA}_{7}-\mathrm{EDC}$ & {$\left[{ }^{2} \mathrm{H}_{2}\right] \mathrm{GA}_{4}$} & 17.2 & 486.3 & $415.1 / 370.1$ & $20 / 30$ & 135 \\
\hline $\mathrm{GA}_{8}-\mathrm{EDC}$ & {$\left[{ }^{2} \mathrm{H}_{2}\right] \mathrm{GA}_{1}$} & 3.8 & 520.3 & $449.4 / 404.2$ & $22 / 32$ & 130 \\
\hline $\mathrm{GA}_{9}-\mathrm{EDC}$ & {$\left[{ }^{2} \mathrm{H}_{2}\right] \mathrm{GA}_{9}$} & 20.0 & 472.3 & $401.2 / 356.2$ & $20 / 30$ & 130 \\
\hline $\mathrm{GA}_{20}-\mathrm{EDC}$ & {$\left[{ }^{2} \mathrm{H}_{2}\right] \mathrm{GA}_{4}$} & 12.5 & 488.4 & $417.5 / 372.2$ & $22 / 33$ & 135 \\
\hline $\mathrm{GA}_{51}-\mathrm{EDC}$ & {$\left[{ }^{2} \mathrm{H}_{2}\right] \mathrm{GA}_{4}$} & 14.5 & 488.3 & $417.1 / 372.2$ & $25 / 35$ & 135 \\
\hline ABA-EDC & {$\left[{ }^{2} \mathrm{H}_{6}\right] \mathrm{ABA}$} & 11.2 & 420.3 & $349.3 / 304.3$ & $15 / 25$ & 135 \\
\hline JA-EDC & {$\left[{ }^{2} \mathrm{H}_{5}\right] \mathrm{JA}$} & 16.0 & 366.3 & $250.2 / 329.2$ & $20 / 12$ & 120 \\
\hline IAA-EDC & {$\left[{ }^{2} \mathrm{H}_{5}\right] \mathrm{IAA}$} & 10.9 & 331.2 & $215.2 / 260.2$ & $18 / 10$ & 120 \\
\hline$\left[{ }^{2} \mathrm{H}_{2}\right] \mathrm{GA}_{1}-\mathrm{EDC}$ & - & 7.6 & 506.4 & $435.4 / 390.3$ & $20 / 34$ & 135 \\
\hline$\left[{ }^{2} \mathrm{H}_{2}\right] \mathrm{GA}_{4}-\mathrm{EDC}$ & - & 17.5 & 490.4 & $419.4 / 374.2$ & $25 / 28$ & 135 \\
\hline$\left[{ }^{2} \mathrm{H}_{2}\right] \mathrm{GA}_{9}-\mathrm{EDC}$ & - & 20.4 & 474.4 & $403.4 / 358.2$ & $20 / 33$ & 135 \\
\hline$\left[{ }^{2} \mathrm{H}_{6}\right]$ ABA-EDC & - & 11.1 & 426.3 & $355.1 / 310.4$ & $17 / 23$ & 135 \\
\hline$\left[{ }^{2} \mathrm{H}_{5}\right] \mathrm{JA}-\mathrm{EDC}$ & - & 16.0 & 371.4 & $300.3 / 255.2$ & $12 / 20$ & 120 \\
\hline$\left[{ }^{2} \mathrm{H}_{2}\right] \mathrm{IAA}-\mathrm{EDC}$ & - & 10.8 & 336.3 & $220.3 / 265.3$ & $18 / 10$ & 100 \\
\hline
\end{tabular}

\section{Figures}
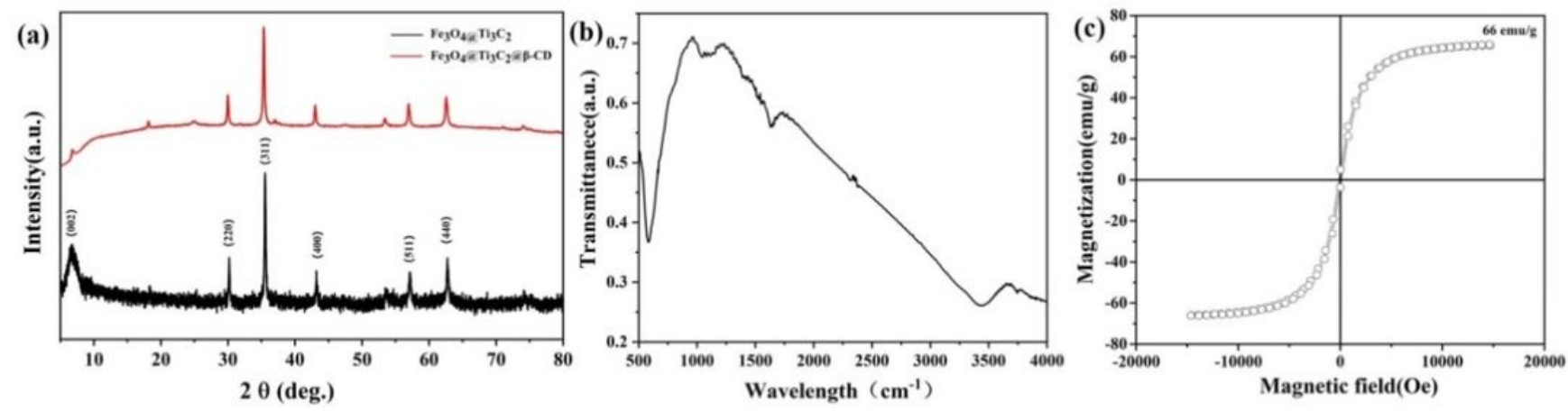

Figure 1

XRD spectrum (a), FI-TR pattern (b), magnetization hysteresis loop (c) of Fe304@Ti3C2@ß-CD 

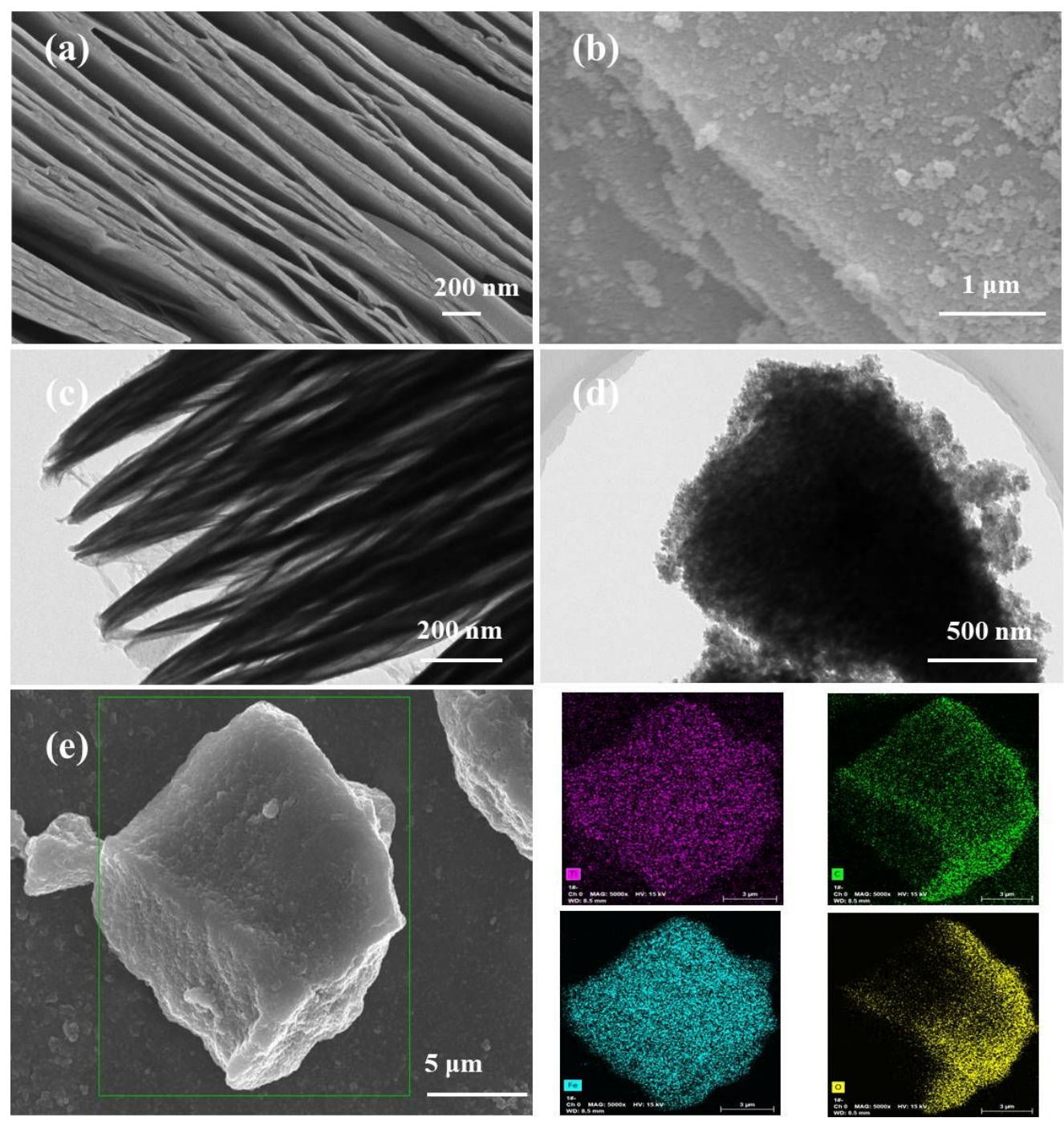

Figure 2

SEM image of Ti3C2 (a), SEM image of Fe304@Ti3C2@ß-CD (b), TEM image of Ti3C2(c), TEM image of Fe304@Ti3C2@ß-CD (d), elemental mapping and chemical composition of Fe304@Ti3C2@ß-CD (e) 

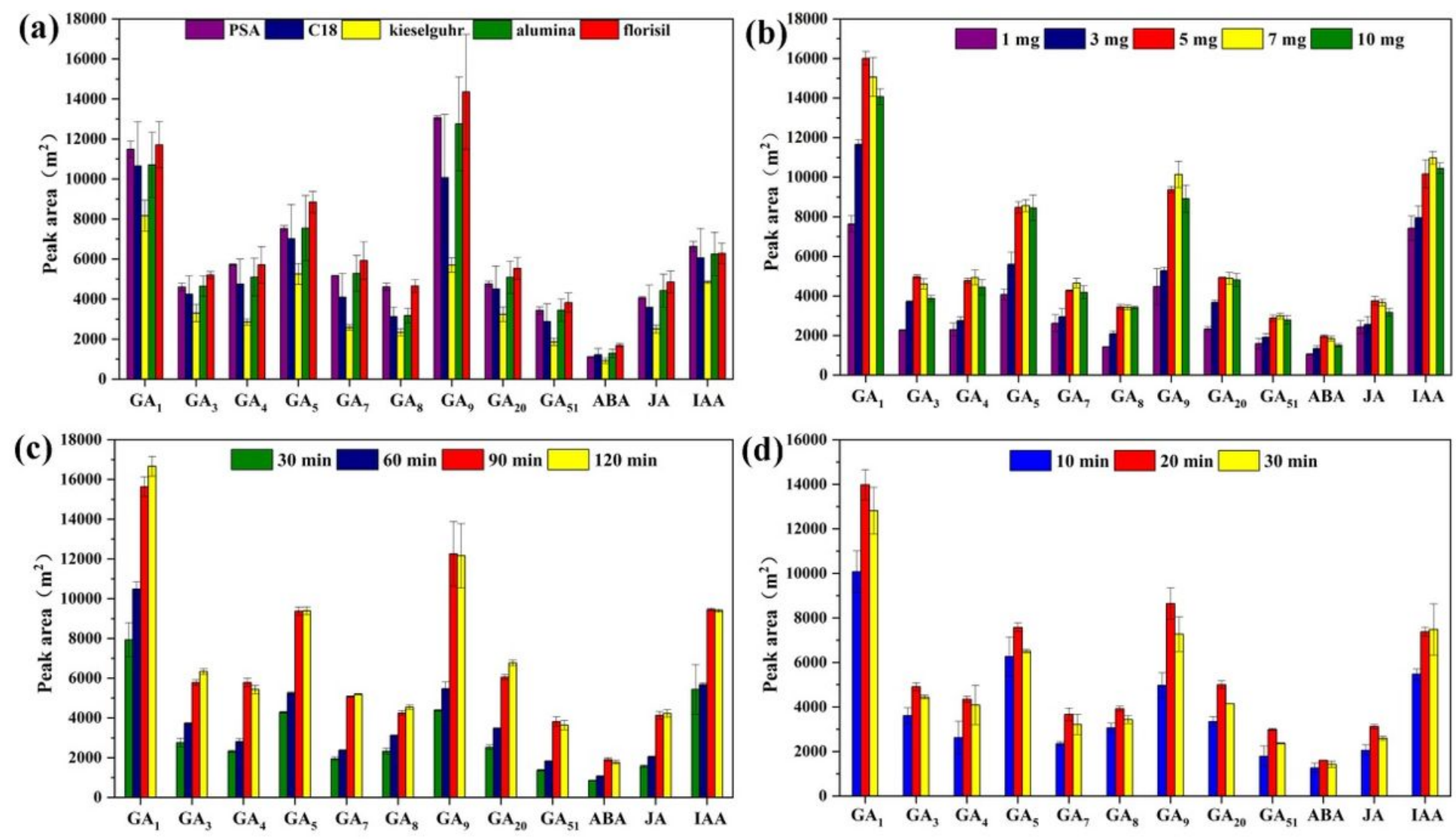

Figure 3

Effects of different cleanup sorbents (a), effects of the amount of magnetic solid-phase extraction sorbents (b), effects of the simultaneous derivatization and magnetic solid phase extraction time (c), effects of the desorption time (d). $5 \mathrm{mg}$ rapeseed spiked with $10 \mathrm{ng} / \mathrm{g}$ of each analyte 


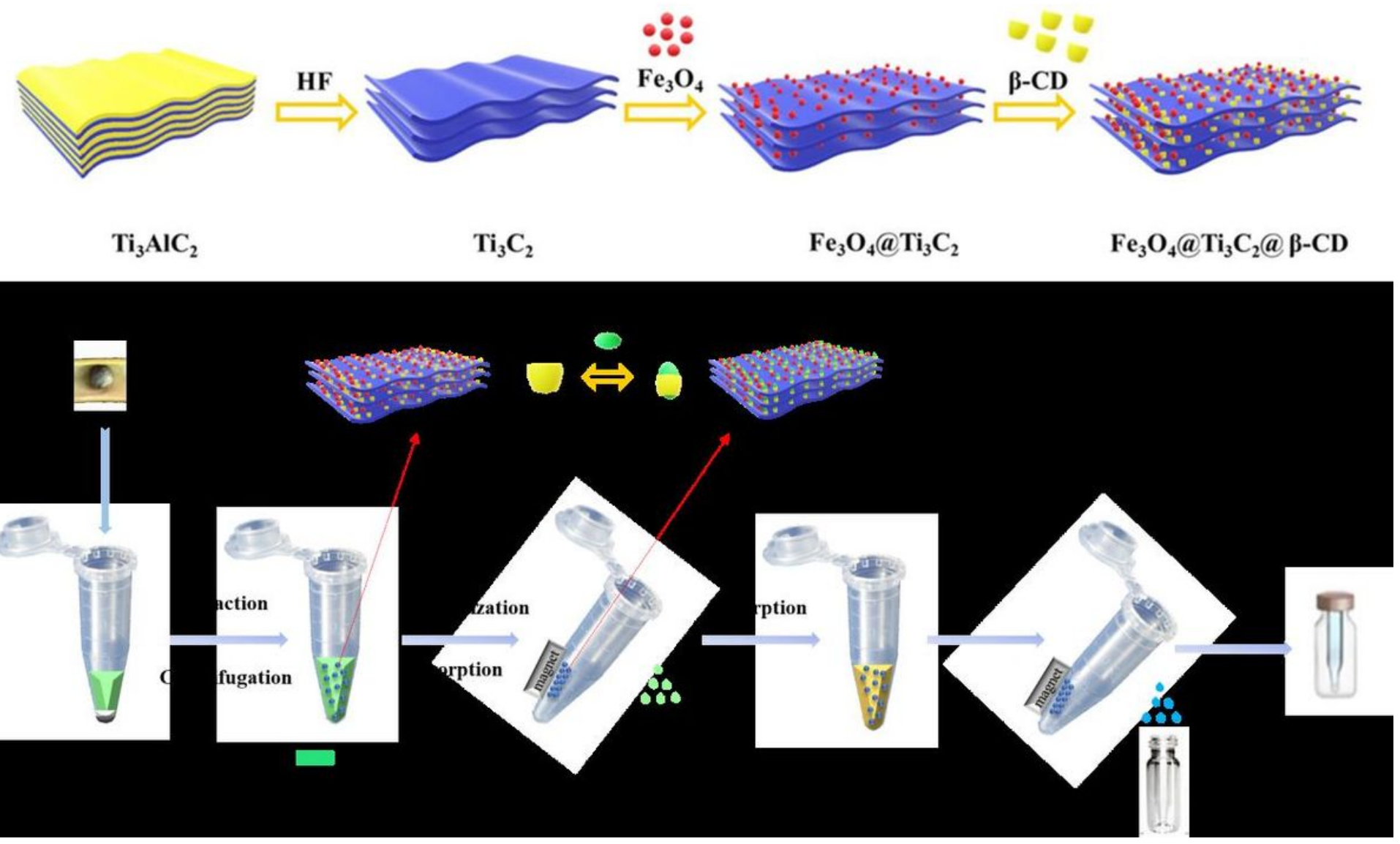

Figure 4

Schematic of the synthetic route for Fe304@Ti3C2@ß-CD and the magnetic solid phase extraction and in situ derivatization procedure

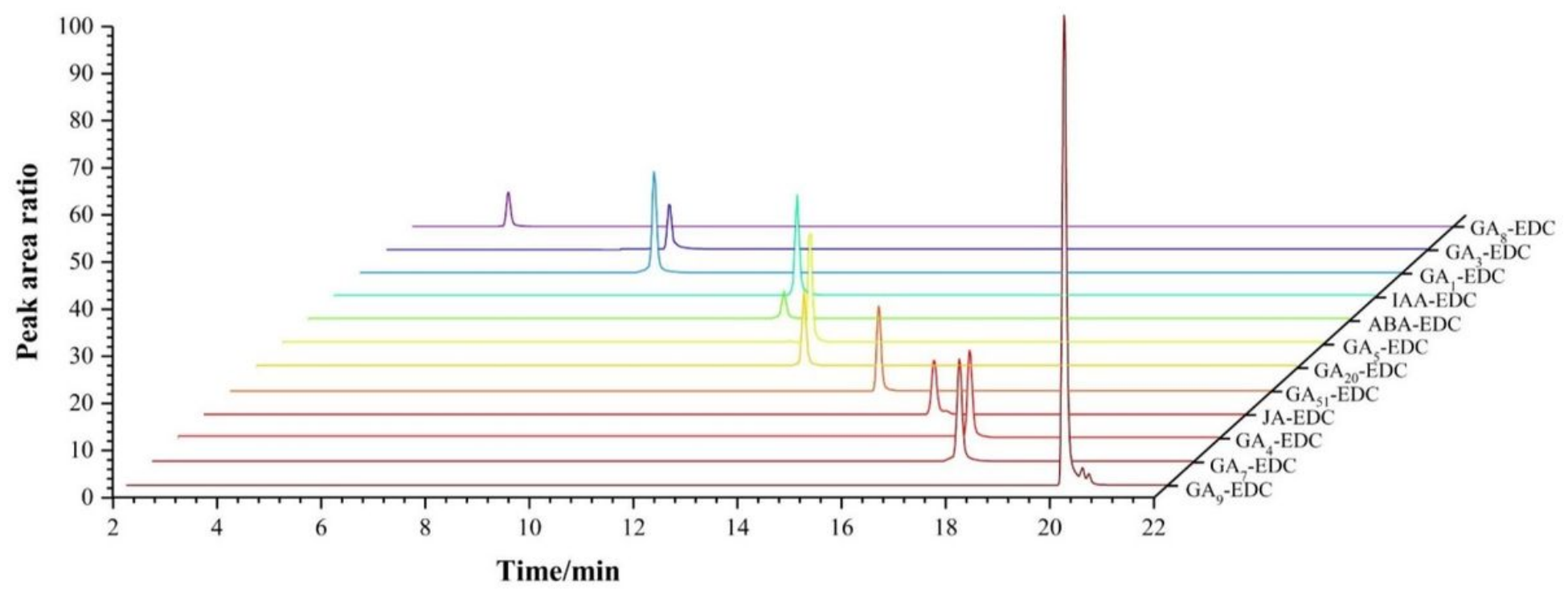

Figure 5

The MRM chromatograms of phytohormone standards $(100 \mathrm{ng} / \mathrm{mL})$ 


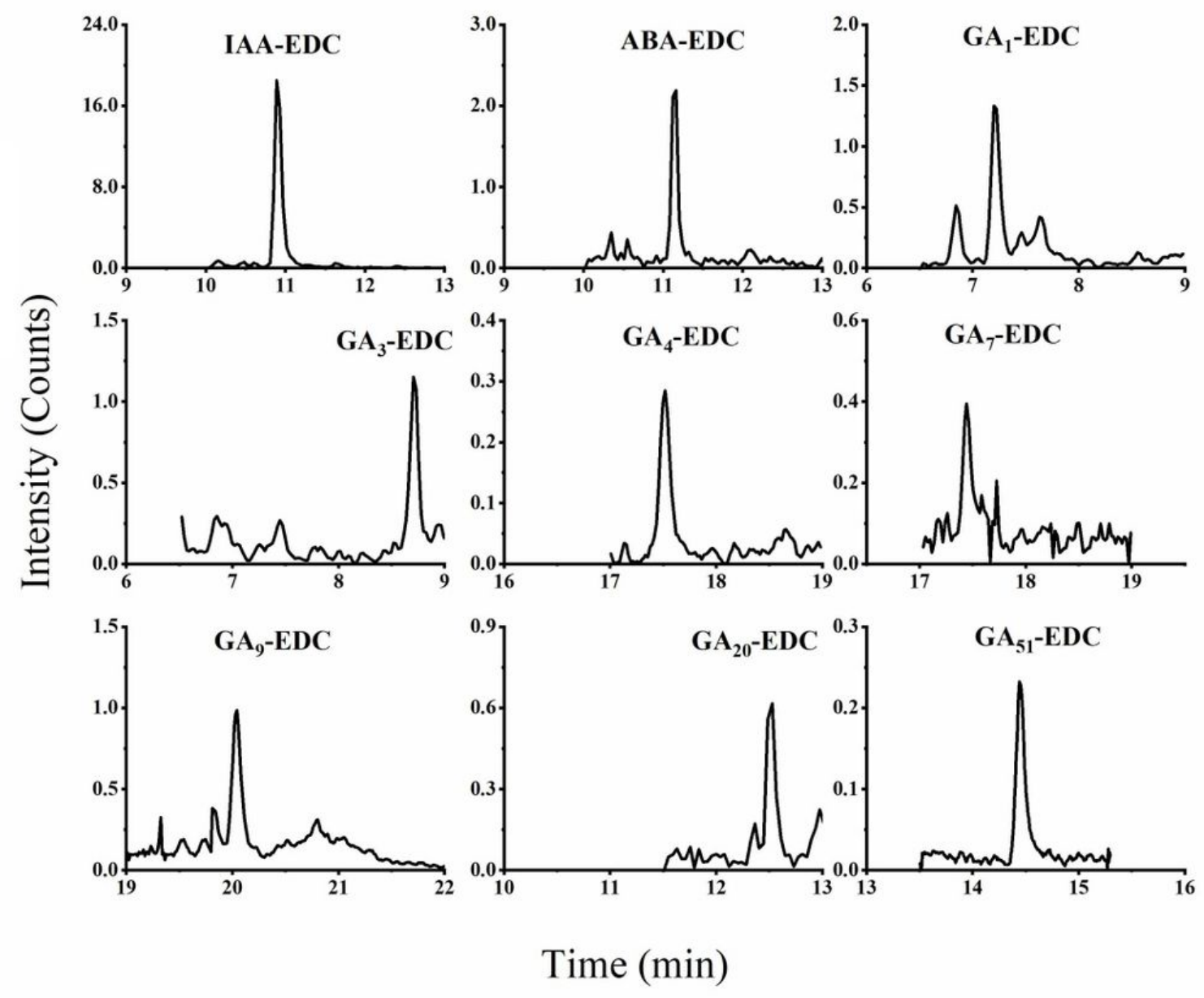

Figure 6

The MRM chromatograms of target phytohormones in a single rapeseed

\section{Supplementary Files}

This is a list of supplementary files associated with this preprint. Click to download.

- CoverLetter.doc

- Supplementarymaterial.docx 